Subscriber access provided by Caltech Library

\title{
Letter
}

\section{Effects of Surface Roughness on the Electrochemical Reduction of CO2 over Cu}

Kun Jiang, Yufeng Huang, Guosong Zeng, Francesca M. Toma, William A. Goddard, and Alexis T. Bell ACS Energy Lett., Just Accepted Manuscript • DOI: 10.1021/acsenergylett.0c00482 • Publication Date (Web): 19 Mar 2020

Downloaded from pubs.acs.org on March 19, 2020

\section{Just Accepted}

"Just Accepted" manuscripts have been peer-reviewed and accepted for publication. They are posted online prior to technical editing, formatting for publication and author proofing. The American Chemical Society provides "Just Accepted" as a service to the research community to expedite the dissemination of scientific material as soon as possible after acceptance. "Just Accepted" manuscripts appear in full in PDF format accompanied by an HTML abstract. "Just Accepted" manuscripts have been fully peer reviewed, but should not be considered the official version of record. They are citable by the Digital Object Identifier (DOI®). "Just Accepted" is an optional service offered to authors. Therefore, the "Just Accepted" Web site may not include all articles that will be published in the journal. After a manuscript is technically edited and formatted, it will be removed from the "Just Accepted" Web site and published as an ASAP article. Note that technical editing may introduce minor changes to the manuscript text and/or graphics which could affect content, and all legal disclaimers and ethical guidelines that apply to the journal pertain. ACS cannot be held responsible for errors or consequences arising from the use of information contained in these "Just Accepted" manuscripts. 


\title{
Effects of Surface Roughness on the Electrochemical Reduction of $\mathrm{CO}_{2}$ over $\mathrm{Cu}$
}

\author{
Kun Jiang, ${ }^{1,2,3 \dagger}$ Yufeng Huang, ${ }^{4 \dagger}$ Guosong Zeng, ${ }^{5}$ Francesca M. Toma, ${ }^{2,5}$ \\ William A. Goddard, III, ${ }^{4}$ and Alexis T. Bell*2,3,5 \\ ${ }^{1}$ Institute of Fuel Cells, School of Mechanical Engineering, Shanghai Jiao Tong University, \\ Shanghai, 200240 \\ ${ }^{2}$ Joint Center for Artificial Photosynthesis, Lawrence Berkeley National Laboratory, \\ Berkeley, California 94720 \\ ${ }^{3}$ Department of Chemical and Biomolecular Engineering, University of California, \\ Berkeley, California 94720 \\ ${ }^{4}$ Materials Simulation Center and Joint Center for Artificial Photosynthesis, \\ California Institute of Technology, Pasadena, California 91125 \\ ${ }^{5}$ Chemical Sciences Division, Lawrence Berkeley National Laboratory, \\ Berkeley, California 94720 \\ †These authors contributed equally to this work.
}

Submitted to

ACS Energy Letters

*To whom correspondence should be sent: alexbell@berkeley.edu 


\begin{abstract}
We have investigated the role of surface roughening on the $\mathrm{CO}_{2}$ reduction reaction $\left(\mathrm{CO}_{2} \mathrm{RR}\right)$ over $\mathrm{Cu}$. The activity and product selectivity of $\mathrm{Cu}$ surfaces roughened by plasma pretreatment in $\mathrm{Ar}$, $\mathrm{O}_{2}$, or $\mathrm{N}_{2}$ were compared with that of electrochemically polished $\mathrm{Cu}$ those. Differences in total and product current densities, the ratio of current densities for HER (the hydrogen evolution reaction) to $\mathrm{CO}_{2} \mathrm{RR}$, and the ratio of current densities for $\mathrm{C}_{2+}$ to $\mathrm{C}_{1}$ products depend on the electrochemically active surface and are nearly independent of plasma composition. Theoretical analysis of an electropolished and roughened $\mathrm{Cu}$ surface reveals a higher fraction of undercoordinated $\mathrm{Cu}$ sites on the roughened surface, sites that bind $\mathrm{CO}$ preferentially. Roughened surfaces also contain square sites similar to those on a $\mathrm{Cu}(100)$ surface but with neighboring step sites, which adsorb $\mathrm{OC}-\mathrm{COH}$, a precursor to $\mathrm{C}_{2+}$ products. These findings explain the increases in the formation of oxygenates and hydrocarbons relative to $\mathrm{CO}$ and the ratio of oxygenates to hydrocarbons observed with increasing surface roughness.
\end{abstract}


Electrochemical $\mathrm{CO}_{2}$ reduction reaction $\left(\mathrm{CO}_{2} \mathrm{RR}\right)$ offers a promising route for the production of chemicals and fuels using renewable electricity generated from wind and solar energy. ${ }^{1-4}$ Among metallic electrocatalysts evaluated for this purpose, copper is the only metal that produces hydrocarbons and oxygenated products with high Faradaic efficiency (FE). ${ }^{5-10}$ Previous studies have shown that the activity and selectivity of $\mathrm{Cu}$ are strongly dependent on the surface morphology of the metal, as well as its local reaction environment (electrolyte composition and pH). ${ }^{11-16}$ For example, $\mathrm{Cu}(100)$ and $\mathrm{Cu}(211)$ surfaces are more active than $\mathrm{Cu}(111)$ surfaces and more effective in promoting $\mathrm{C}-\mathrm{C}$ bond formation on both single crystal $\mathrm{Cu}$ electrodes ${ }^{17,18}$ and $\mathrm{Cu}$ nanoparticles. ${ }^{19,} 20$ Recent theoretical calculations have shown that square sites of $\mathrm{Cu}(100)$ bind *OCCO and *OCCHO more strongly than do sites on $\mathrm{Cu}(111)$, and that the step sites of $\mathrm{Cu}(211)$ facilitate the kinetics of $\mathrm{CO}$ dimerization relative to those on $\mathrm{Cu}(111)$, resulting in a higher $\mathrm{C}_{2} / \mathrm{C}_{1}$ selectivity on square and stepped facets. ${ }^{21,22}$ The role of other low-coordination $\mathrm{Cu}$ sites beyond those present on low-index facets is the subject of continuing discussion. An investigation of the $\mathrm{CO}_{2} \mathrm{RR}$ over size-controlled $\mathrm{Cu}$ nanoparticles has also shown that the population of lowcoordination $\mathrm{Cu}$ surface sites increases with decreasing $\mathrm{Cu}$ particle size (from $15 \mathrm{~nm}$ to $2 \mathrm{~nm}$ ), and that high coordination site result in higher $\mathrm{H}_{2}$ and $\mathrm{CO}$ selectivities and lower hydrocarbon $\left(\mathrm{CH}_{4}\right.$ and $\mathrm{C}_{2} \mathrm{H}_{4}$ ) selectivities. ${ }^{23}$ By contrast, a comparative investigation of $\mathrm{CO}_{2} \mathrm{RR}$ on (100)-, (111)-, and (751)-preferentially orientated $\mathrm{Cu}$ thin film electrodes revealed that both $\mathrm{Cu}(100)$ and (751) surfaces with $\mathrm{Cu}$ coordination numbers from 6 to 8 promote $\mathrm{C}-\mathrm{C}$ bond formation relative to more highly coordinated sites on $\mathrm{Cu}(111)$ surfaces. ${ }^{24}$ More recently, a study of the electrochemical reduction of $\mathrm{CO}$ has suggested that highly porous $\mathrm{Cu}$ electrode could favor $\mathrm{C}_{2+}$ oxygenates selectivity with a large suppression of competitive HER; however, the underlying causes for these observations remains unclear. ${ }^{25}$

Oxide-derived $\mathrm{Cu}$ with enriched surface grain boundaries have also been reported to be efficient for reducing $\mathrm{CO}_{2}$ to multi-carbon products. ${ }^{26-29}$ It has been hypothesized that this enhanced $\mathrm{C}_{2+}$ products selectivity on oxide-derived $\mathrm{Cu}$ could arise from surface $\mathrm{Cu}^{+}$retained under reaction conditions and stabilized by subsurface oxygen ${ }^{28,30}$ or adsorbed halide anions, ${ }^{31,} 32$ e.g., $\mathrm{I}^{-}$, based on quasi in situ spectroscopic experiments. However, this hypothesis has been challenged by recent DFT calculations, ${ }^{33,} 34{ }^{18} \mathrm{O}$ labeling, ${ }^{35}$ electrochemical Raman spectroscopy ${ }^{36,37}$ and in situ synchrotron XAS and XRD experiments, ${ }^{38,39}$ suggesting the near-surface oxygen and/or $\mathrm{Cu}(\mathrm{I})$ species are not sufficiently long-lived to be present under reaction conditions at highly reducing 
cathode potentials. ${ }^{40}$ A more plausible interpretation for the enhanced $\mathrm{C}_{2+}$ selectivity of oxidederived $\mathrm{Cu}$ is offered by a recent theoretical analysis of sites present on a rough $\mathrm{Cu}$ nanoparticle. This work concludes that surface twin boundaries in the oxide-derived $\mathrm{Cu}$ associated with concave defects with respect to $\mathrm{Cu}(100)$ planes serve as active sites for $\mathrm{C}-\mathrm{C}$ bond formation by stabilizing OC-COH species, one of the precursors to $\mathrm{C}_{2+}$ products. $^{41}$

In this study, we investigate the effects of plasma pretreatment of polished $\mathrm{Cu}$ foils in different gas atmospheres on their $\mathrm{CO}_{2} \mathrm{RR}$ activity and selectivity. Since $\mathrm{O}_{2}$-plasma treatment will cause both chemical and physical modifications to $\mathrm{Cu}$ surfaces, we pretreated $\mathrm{Cu}$ by $\mathrm{Ar}^{+}$ion bombardment in an Ar plasma in order to isolate the effects of surface roughening. These studies show that the changes in the distribution of $\mathrm{CO}_{2} \mathrm{RR}$ products is attributable to changes $\mathrm{Cu}$ surface topography created by the plasma pre-treatments. Roughened $\mathrm{Cu}$ surfaces containing a high proportion of under-coordinated $\mathrm{Cu}$ sites that exhibit stronger $\mathrm{CO}$ adsorption energies than more highly coordinated site present of planar surfaces. Consistent with this finding, the fraction of $\mathrm{CO}$ formed from $\mathrm{CO}_{2}$ released as $\mathrm{CO}$ decreases and the fraction converted to hydrocarbons and alcohols increases with increasing roughness. Our experimental efforts are supported by an analysis of the distribution of sites on a simulated roughened surface of $\mathrm{Cu}$. This work shows that the roughened surface contains a much higher proportion of under-coordinated sites, and in particular sites that adsorb $\mathrm{OCCOH}$, a suggested precursor to $\mathrm{C}_{2+}$ products, ${ }^{41}$ more strongly than do the more highly coordinated sites present on a $\mathrm{Cu}(100)$ surface.

\section{$\underline{\text { Surface Characterization Before and After Plasma Pre-treatment }}$}

Figures 1A and 1B show atomic force microscopy (AFM) and scanning electron microscopy (SEM) images, respectively of the electrochemically polished $\mathrm{Cu}$ foil. Fig. 1C presents the AFM topography image of $\mathrm{Cu}$ foil after 10-min Ar plasma treatment. In contrast to the polished foil, the Ar plasma-treated foil is much rougher, exhibiting extensive ridges and valleys. ${ }^{42}$ The arithmetic surface roughness factor $\left(S_{a}\right)$ increases from $1.28 \mathrm{~nm}$ for the electropolished foil to 7.68 $\mathrm{nm}$ after $\mathrm{Ar}^{+}$sputtering based on an AFM scan of a $500 \mathrm{~nm}$ x $500 \mathrm{~nm}$ area (Fig. S1). SEM images of Ar plasma treated $\mathrm{Cu}$ foil before and after $\mathrm{CO}_{2} \mathrm{RR}$ electrolysis are shown in Fig. 1D. In agreement with the topography determined by AFM, the $2 \mathrm{D}$ projection exhibits a surface structure 
covered with pits and islands generated by $\mathrm{Ar}^{+}$bombarding and re-deposition of $\mathrm{Cu}$ atoms. Similar surface roughening effects were also observed for $\mathrm{N}_{2}$ and $\mathrm{O}_{2}$ plasma treated $\mathrm{Cu}$ foils (Fig. S2).

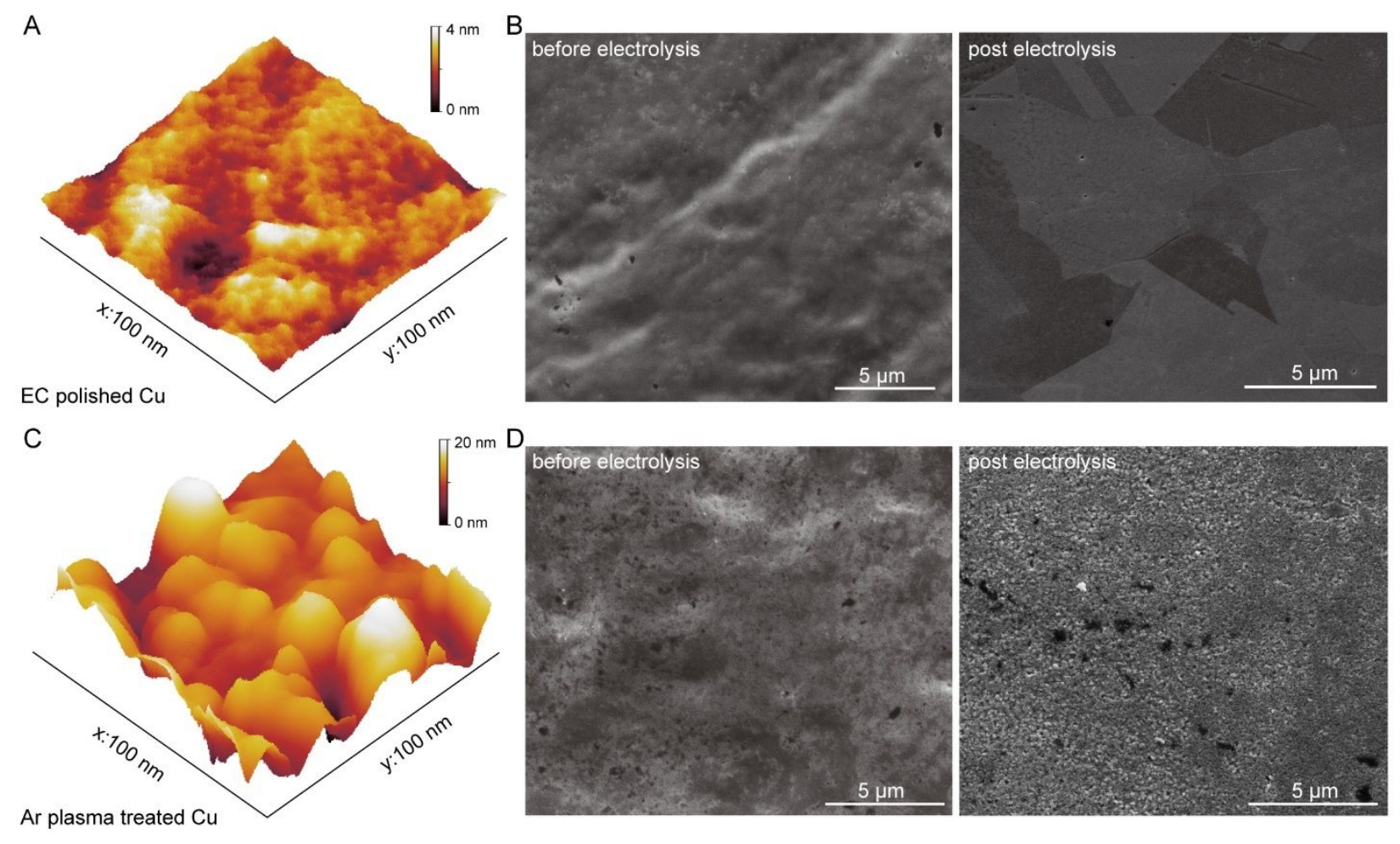

Figure 1. $\mathrm{Cu}$ electrodes characterization. AFM and SEM images of electrochemically polished $\mathrm{Cu}$ foil (A, B) acquired before and after a 10-min plasma pre-treatment in Ar. Images (A) and (C) show the reconstructed 3D topography of the surface obtained from AFM scans, images (B) and (D) show typical $\mathrm{SEM}$ images of $\mathrm{Cu}$ foils taken before and after 1-h $\mathrm{CO}_{2} \mathrm{RR}$ electrolysis at $-1.0 \mathrm{~V}$ in $\mathrm{CO}_{2}$-saturated $0.1 \mathrm{M}$ $\mathrm{CsHCO}_{3}$.

To further quantify the surface roughness of $\mathrm{Cu}$ foils electrodes, we determined the electrochemically active surface area (ECSA) by measuring the double-layer capacitances and then calculating the relative roughness of plasma pre-treated $\mathrm{Cu}$ compared to electropolished $\mathrm{Cu}$ (Table 1 and Fig. S3). In general, all of the plasma treatments increased the roughness of $\mathrm{Cu}$, and prolonged pretreatment time led to a more roughened surface. For the same pretreatment duration, $\mathrm{Cu}$ foils treated in either an $\mathrm{Ar}$ or $\mathrm{O}_{2}$ plasma were rougher than that exposed to an $\mathrm{N}_{2}$ plasma. These differences are likely due to the larger ion size of $\mathrm{Ar}^{+}$, the more aggressive etching of $\mathrm{O}^{2-},{ }^{43}$, 44 as well as the pronounced surface structural rearrangement caused by removal of oxygen from copper oxide during electrochemical reduction. ${ }^{26,34} \mathrm{We}$ also note that plasma pretreatment in an 
$\mathrm{N}_{2}$ plasma for more than $10 \mathrm{~min}$ did not increase the surface roughness of $\mathrm{Cu}$ further, in contrast to what was observed for pretreatment in an $\mathrm{O}_{2}$ plasma.

Table 1. Determined surface roughness of post electrolysis $\mathrm{Cu}$ foils with different plasma pretreatments.

\begin{tabular}{|c|c|c|c|c|c|c|c|c|}
\hline \multirow{2}{*}{ Electrode } & \multirow{2}{*}{$\begin{array}{l}\text { Electro- } \\
\text { polished }\end{array}$} & \multirow{2}{*}{$\begin{array}{c}\mathrm{N}_{2} \text { Plasma } \\
10 \text {-min }\end{array}$} & \multicolumn{3}{|c|}{ Ar Plasma } & \multicolumn{3}{|c|}{$\mathrm{O}_{2}$ Plasma } \\
\hline & & & 5-min & 10-min & 20-min & 5-min & 10-min & 20-min \\
\hline Roughness & 1.00 & 1.57 & 1.42 & 2.58 & 3.64 & 1.85 & 2.92 & 3.93 \\
\hline
\end{tabular}

A

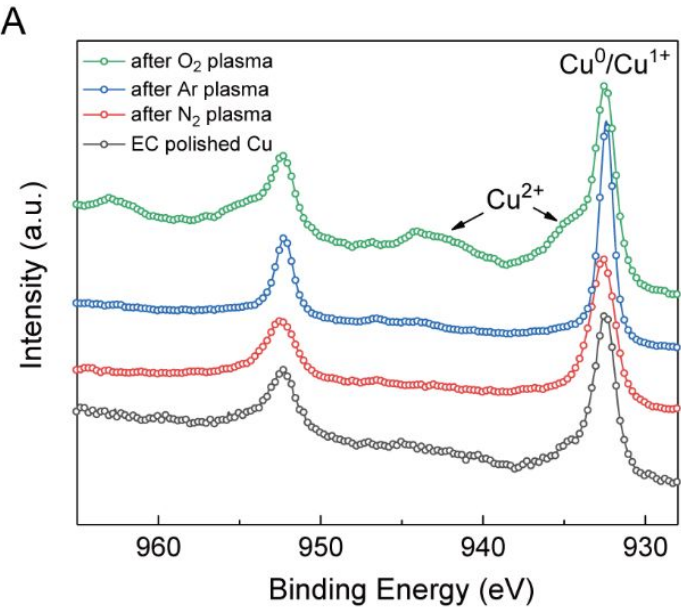

B

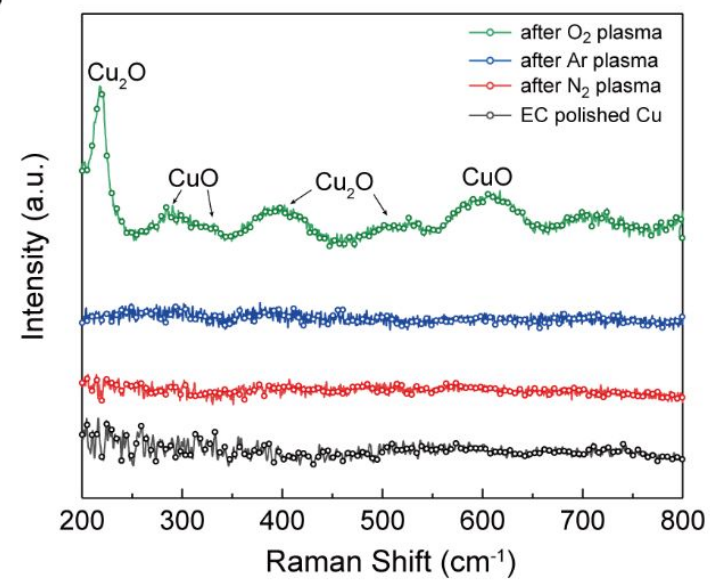

Figure 2. Chemical state characterization of $\mathrm{Cu}$ electrodes. Ex situ (A) XPS and (B) Raman spectra recorded on $\mathrm{Cu}$ foils after 10-min plasma treatments under different gaseous atmosphere.

Figure 2A shows the ex-situ core level X-ray photoelectron spectra (XPS) of the $\mathrm{Cu} 2 \mathrm{p}$ region after plasma treatments in different atmospheres. All four samples show the predominant peak at $932.4\left(\mathrm{Cu} 2 \mathrm{p}_{3 / 2}\right)$ and $952.2 \mathrm{eV}\left(\mathrm{Cu} 2 \mathrm{p}_{1 / 2}\right)$, corresponding to $\mathrm{Cu}(0)$ or $\mathrm{Cu}(\mathrm{I})$. For the $\mathrm{O}_{2}$ plasma treated $\mathrm{Cu}$, two other satellite peaks show up at $\sim 935 \mathrm{eV}$ and $\sim 944 \mathrm{eV}$, which are assigned to $\mathrm{Cu}$ (II) species. Evidence for $\mathrm{Cu}(\mathrm{II})$ cation was also obtained from the $\mathrm{Cu}$ LMM region of the Auger spectrum (see Fig. S4). Raman spectra of these four Cu samples are shown in Fig. 2B. No obvious Raman scattering feature is observed for electropolished $\mathrm{Cu}$ or $\mathrm{Cu}$ exposed to a $\mathrm{N}_{2}$ or an Ar plasma. By contrast, features for both $\mathrm{Cu}_{2} \mathrm{O}\left(\sim 218,402\right.$ and $\left.526 \mathrm{~cm}^{-1}\right)$ and $\mathrm{CuO}\left(\sim 290,332\right.$ and $\left.617 \mathrm{~cm}^{-1}\right)$ are observed after $\mathrm{O}_{2}$ plasma pretreatment, ${ }^{45}$ in agreement with XPS spectra and Raman studies reported previously. ${ }^{28,32}$ 


\section{Electrochemical Activity and Selectivity}

A

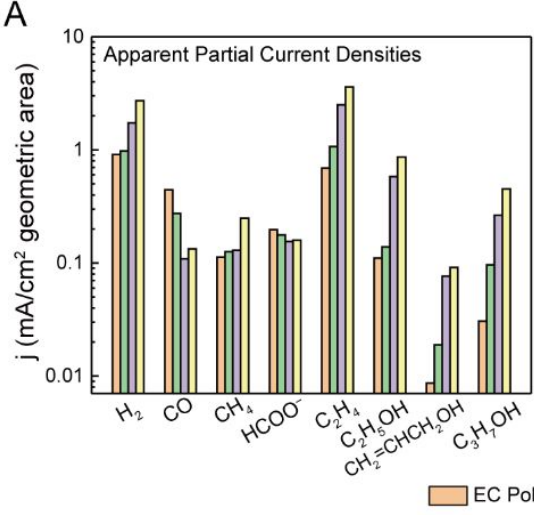

B

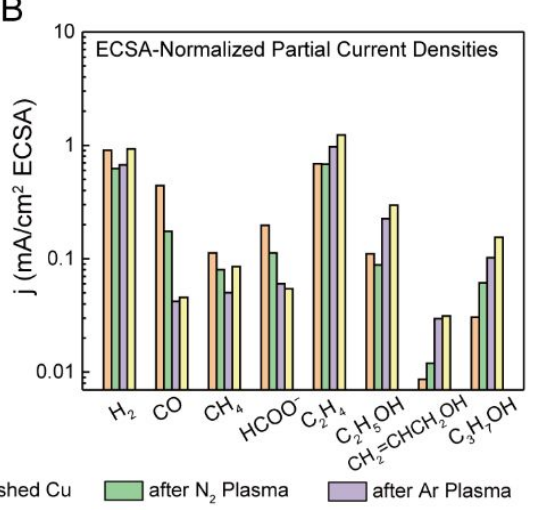

C

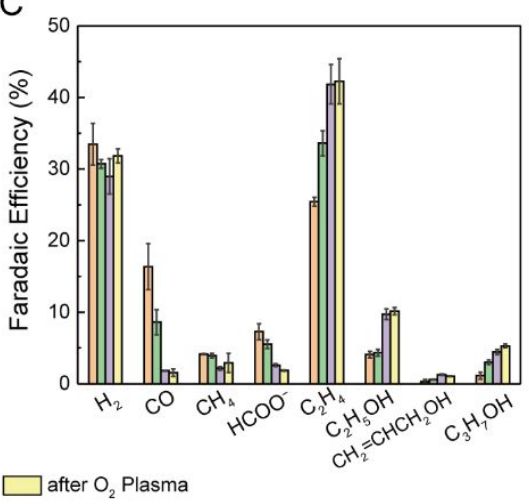

Figure 3. Electrochemical reduction of $\mathrm{CO}_{2}$ over $\mathrm{Cu}$ foil electrodes after 10-min plasma pretreatments under different gaseous atmosphere. (A) Geometric area normalized, (B) ECSA-normalized partial current densities and $(\mathrm{C})$ selectivity of major products during $\mathrm{CO}_{2} \mathrm{RR}$ over $\mathrm{Cu}$ foil electrodes after 10-min plasma pre-treatments under different atmosphere.

The electrochemical $\mathrm{CO}_{2} \mathrm{RR}$ performance of plasma pre-treated $\mathrm{Cu}$ foils was evaluated by 1 $\mathrm{h}$ chronoamperometric electrolysis at $-1.0 \mathrm{~V}$ vs. $\mathrm{RHE}$, for which the $\mathrm{CO}_{2}$ consumption rate is below $17.0 \mathrm{nmol} \mathrm{s}^{-1} \mathrm{~cm}^{-2}$ (Fig. S5). ${ }^{46} 0.1 \mathrm{M} \mathrm{CsHCO}_{3}$ was employed as the supporting electrolyte, based upon our previous studies showing that $\mathrm{Cs}^{+}$cations enhance the field stabilization of the intermediates critical to the formation $\mathrm{C}_{2}$ products ${ }^{13,14,47}$ (further evidence for influence of cation identity is given in Fig. S6). The superficial current densities shown in Fig. 3A all increase with plasma pretreatment, in the order of the increasing ECSA. To account for this effect, Fig. 3B shows the current densities for all four samples normalized by the ECSA. The ECSA-normalized current densities for $\mathrm{H}_{2}$ and $\mathrm{CH}_{4}$ are not strongly changed by plasma pretreatment, whereas those for $\mathrm{CO}$ and $\mathrm{HCOO}^{-}$decreases and those for all $\mathrm{C}_{2+}$ product increases in the order no pretreatment $<\mathrm{N}_{2}$ plasma pretreatment $<$ Ar plasma pretreatment $<\mathrm{O}_{2}$ plasma pretreatment. We note in particular that the rate of $\mathrm{CO}$ evolution decreases by more than an order of magnitude upon $\mathrm{Ar}$ or $\mathrm{O}_{2}$ plasma pretreated $\mathrm{Cu}$ compared to that for electropolished $\mathrm{Cu}$, and the rate of $\mathrm{C}_{3}$ products generation allyl alcohol and n-propanol - increases by a factor of 3 to 5 . The FEs of the principal products of the $\mathrm{CO}_{2} \mathrm{RR}$ generated on electropolished and plasma pretreated $\mathrm{Cu}$ are illustrated in Fig. 3C. After 10-min plasma pretreatment, the selectivity toward hydrogen evolution (HER) and methane generation does not change very much, while the FEs for $\mathrm{CO}$ and $\mathrm{HCOO}^{-}$decrease in the order of 
polished $\mathrm{Cu}>\mathrm{N}_{2}$ plasma pretreated $\mathrm{Cu}>$ Ar plasma pretreated $\mathrm{Cu} \approx \mathrm{O}_{2}$ plasma pretreated $\mathrm{Cu}$. By contrast, the FEs for $\mathrm{C}_{2+}$ products $-\mathrm{C}_{2} \mathrm{H}_{4}, \mathrm{C}_{2} \mathrm{H}_{5} \mathrm{OH}$ and n-propanol - follow the reverse trend.

A

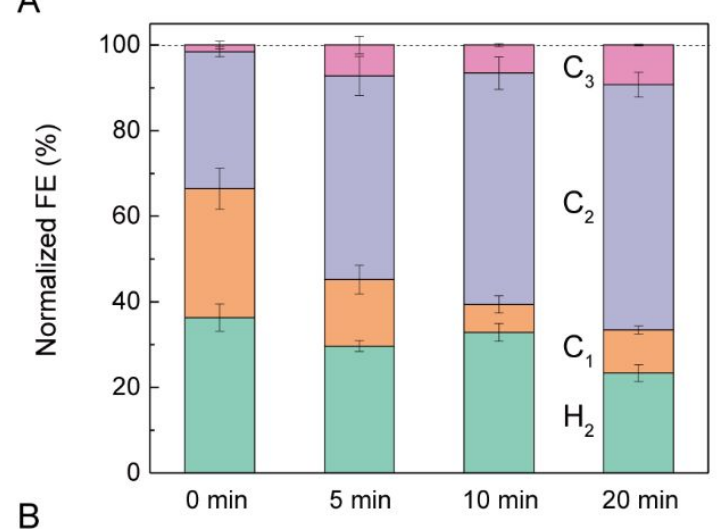

B

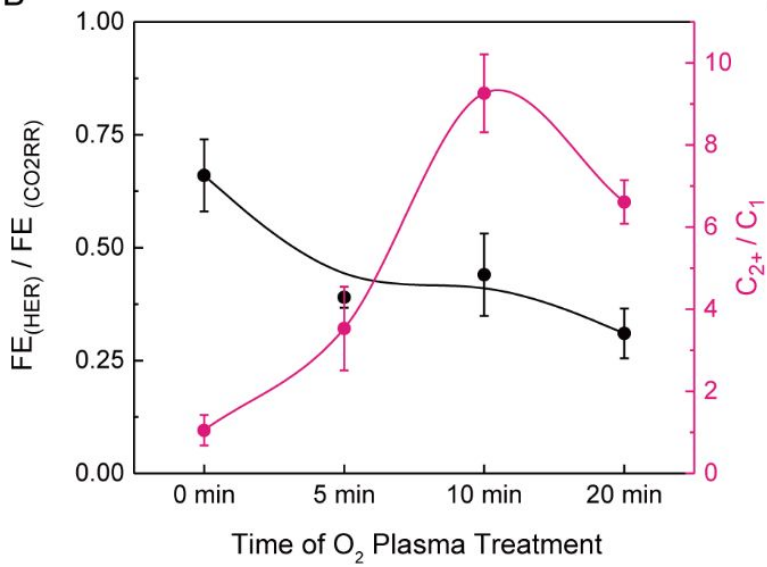

C
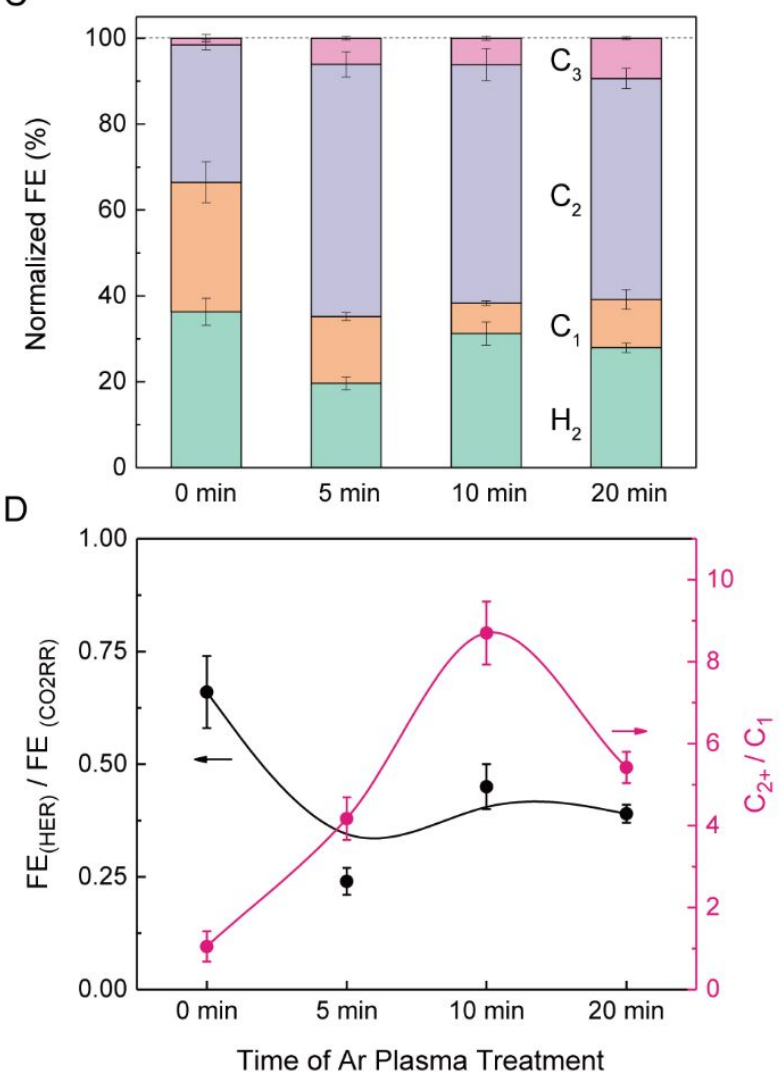

Figure 4. $\mathrm{CO}_{2} \mathrm{RR}$ products distribution as a function of plasma treatment time. Both (A, $\left.\mathrm{B}\right) \mathrm{O}_{2}$ and $(\mathrm{C}, \mathrm{D})$ Ar atmosphere plasma pretreatments were plotted. The sum of as-determined overall FEs are varied from $92.2 \%$ to $98.9 \%$ and all normalized to $100 \%$ in panels (A) and (C) for comparison.

The similarity of both $\mathrm{C}_{2+}$ product selectivities and specific activities of $\mathrm{Cu}$ after $\mathrm{Ar}$ or $\mathrm{O}_{2}$ pretreatment is particularly interesting. Therefore, we investigated the effects of the duration of plasma pretreatment in $\mathrm{Ar}$ and $\mathrm{O}_{2}$ on the distribution of $\mathrm{CO}_{2} \mathrm{RR}$ products. Fig. 4 shows these results for durations of 0,510 , and $20 \mathrm{~min}$, with the electropolished sample referenced as 0 -min. The normalized FEs (referenced to 100\%) are given in Figs. 4A and 4C. The FE for HER is cyan column, the $\mathrm{FE}$ for $\mathrm{C}_{1}$ products $\left(\mathrm{HCOO}^{-}, \mathrm{CO}\right.$ and $\left.\mathrm{CH}_{4}\right)$ is orange column, the $\mathrm{FE}$ for $\mathrm{C}_{2}$ products $\left(\mathrm{C}_{2} \mathrm{H}_{4}\right.$ and $\left.\mathrm{C}_{2} \mathrm{H}_{5} \mathrm{OH}\right)$ is purple column, and the $\mathrm{FE}$ for $\mathrm{C}_{3}$ products (allyl alcohol and n-propanol) is magenta column. The selectivity ratio of $\mathrm{HER} / \mathrm{CO}_{2} \mathrm{RR}$ (black line) and the $\mathrm{C}_{2+} / \mathrm{C}_{1}$ ratio (red line) are illustrated in Figs. 4B and 4D. We observe similar product distributions throughout the time- 
course for both $\mathrm{O}_{2}$ and Ar plasma pre-treatments, which could largely rule out the (sub)surface oxygen effect. HER decreases to below 30\% after 5-min plasma exposure in both cases and levels off with prolonged exposure. The $\mathrm{FE}$ for $\mathrm{C}_{1}$ products also decreases from 0 to $10 \mathrm{~min}$, then increases again due to enhanced methane evolution after a 20-min pretreatment. Over the same pretreatment time, the $\mathrm{FE}$ for $\mathrm{C}_{3}$ alcohols reaches $\sim 10 \%$, whereas the $\mathrm{FE}$ for $\mathrm{C}_{2+}$ products rises to $\sim 60 \%$. The ratio of $\mathrm{C}_{2+} / \mathrm{C}_{1}$ reaches a maximum value of $\sim 9$ after 10 -min of pretreatment in either an $\mathrm{Ar}$ or $\mathrm{O}_{2}$ plasma.

Since the $\mathrm{Cu}$ surface roughness increases with prolonged plasma-treatment time, we assessed whether the changes shown in Fig. 4 correlate with surface roughness. The choice of which product ratios to plot is guided by recent theoretical studies of the $\mathrm{CO}_{2} \mathrm{RR}$ mechanism, which suggest that $2 \mathrm{e}^{-}$products $\left(\mathrm{HCOO}^{-}\right.$and $\left.\mathrm{CO}_{\mathrm{g}}\right)$ are produced via the adsorbed intermediates $* \mathrm{HCOO}$ and $* \mathrm{COOH}$, respectively, whereas both $\mathrm{CH}_{4}$ and $\mathrm{C}_{2+}$ products are produced via the reduction of *CO. ${ }^{5,6,48-51}$ Therefore, as illustrated in Fig. $5 \mathrm{~A}$, ${ }^{*} \mathrm{CO}$ serves as the key intermediate to $\mathrm{CH}_{4}$ and $\mathrm{C}_{2+}$ products. Figures $5 \mathrm{~B}$ and $5 \mathrm{C}$ plot the selectivity ratios for $\mathrm{C}_{2+}$ products versus $\mathrm{C}_{1}$ products $\left(\mathrm{HCOO}^{-}, \mathrm{CO}\right.$, and $\mathrm{CH}_{4}$ ) and versus $\mathrm{CH}_{4}$ alone, respectively. The $\mathrm{C}_{2+} / \mathrm{C}_{1}$ ratio reaches a value of $\sim 9$ for a roughness of $\sim 3$ and then decreases thereafter, regardless of whether $\mathrm{Cu}$ is pretreated in an $\mathrm{Ar}$ or $\mathrm{O}_{2}$ plasma. By contrast, the $\mathrm{C}_{2+} / \mathrm{CH}_{4}$ ratio increases monotonically to a value of 30 in the case of Ar plasma pretreatment but reaches a maximum value of $\sim 20$ and then decreases in the case of $\mathrm{O}_{2}$ pretreatment. 
A

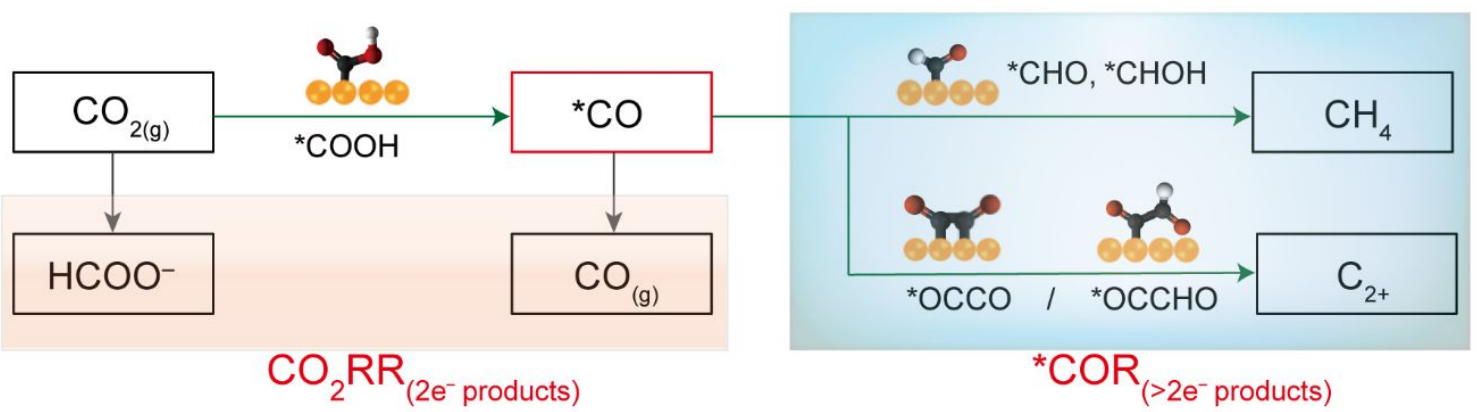

B

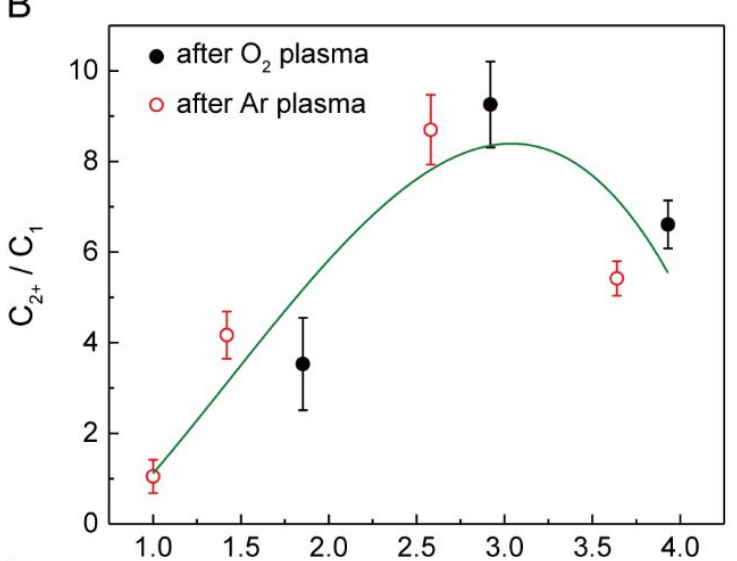

C
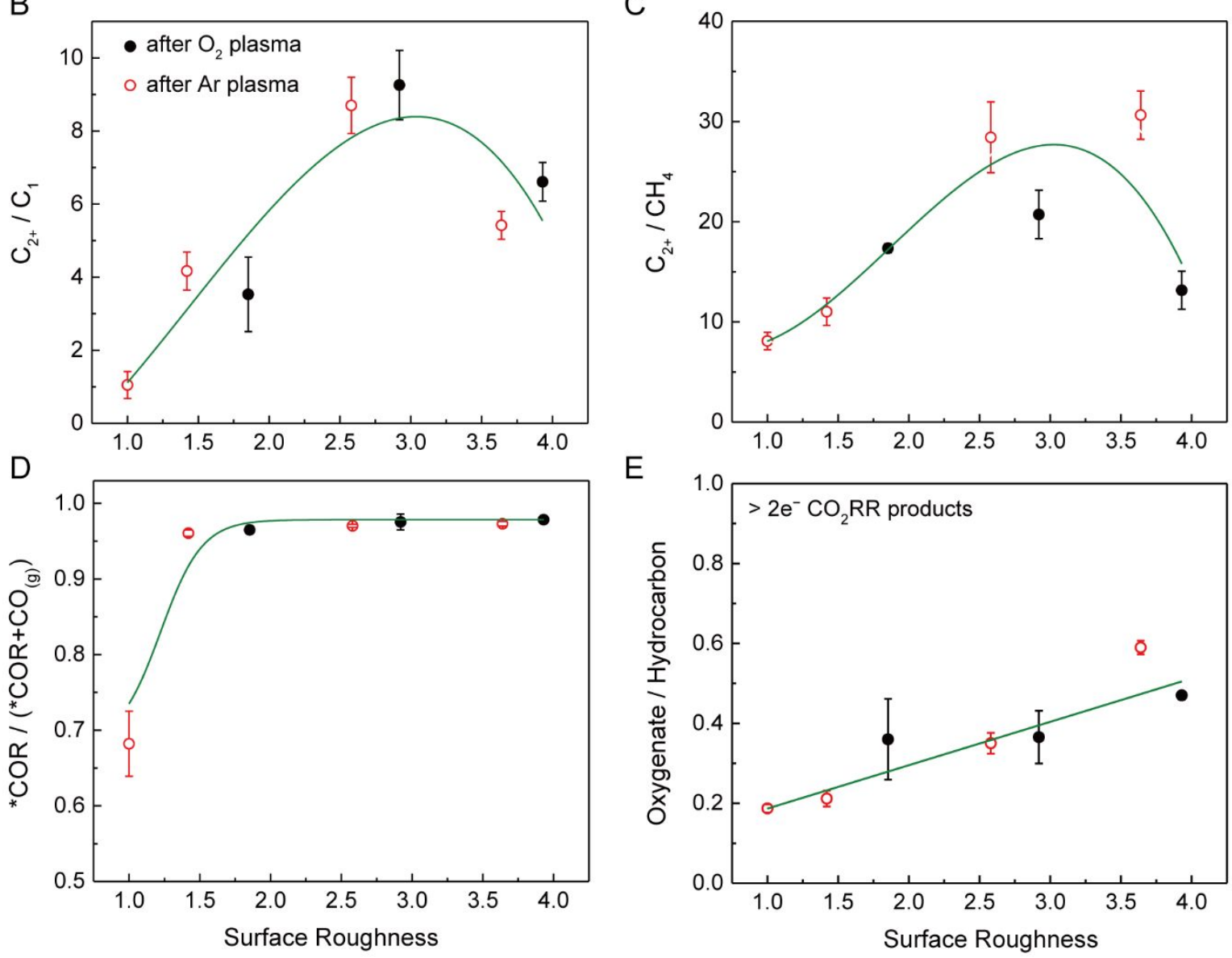

Figure 5. $\mathrm{CO}_{2} \mathrm{RR}$ products distribution as a function of $\mathrm{Cu}$ surface roughness. (A) Simplified flowchart of $\mathrm{CO}_{2} \mathrm{RR}$ mechanism leading to $\mathrm{C}_{1}$ and $\mathrm{C}_{2+}$ products generation, * corresponds to adsorbed species, $>2 \mathrm{e}$ reduction products of $\mathrm{CH}_{4}$ and $\mathrm{C}_{2+}$ that go through the reduction of * $\mathrm{CO}$ intermediate $(* \mathrm{COR})$ are marked in light blue. (B) $\mathrm{C}_{2+} / \mathrm{C}_{1}$ ratio, (C) $\mathrm{C}_{2+} / \mathrm{C}_{\mathrm{CH} 4}$ ratio, (D) $* \mathrm{COR} /\left(\mathrm{CO}_{(\mathrm{g})}+* \mathrm{COR}\right)$ ratio, and (E) oxygenate/hydrocarbon (only $>2$ e reduction products) ratio.

Figure 5D show that the fraction of $\mathrm{CO}$ produced by the $\mathrm{CO}_{2} \mathrm{RR}$ converted to $\mathrm{CH}_{4}$ and $\mathrm{C}_{2+}$ products increases from 0.68 for a roughness of 1.0 to 0.96 for a roughness of 1.5. Further increasing the roughness to $\sim 4.0$ increases this ratio to 0.98 . The trend observed in Fig. 5D suggests 

simulated $\mathrm{Cu}$ particle surface. ${ }^{41,52}$ The theoretical work also predicts that the stability of *OC$\mathrm{COH}$, a critical precursor to $\mathrm{C}_{2}$ products, increases with surface roughness and in particular with the formation of concave sites at grain boundaries between $\mathrm{Cu}(100)$ and $\mathrm{Cu}(111)$ surfaces. The downturn in the ratio of FEs for $\mathrm{C}_{2+}$ product formation and $\mathrm{CH}_{4}$ formation seen in $\mathrm{Fig}$. $5 \mathrm{C}$ when the roughness exceeds $\sim 3.0$ for $\mathrm{O}_{2}$ plasma pretreated $\mathrm{Cu}$ might be attributable to the formation of sub-nanometric $\mathrm{Cu}$ clusters (i.e., surface dimer and trimer adatoms) that could serve as active sites for selective $\mathrm{CO}_{2}$-to- $\mathrm{CH}_{4}$ conversion. ${ }^{53}$ Finally, Fig. $5 \mathrm{E}$ shows the surface roughness dependence of the ratio of $\mathrm{FEs}$ for $\mathrm{C}_{2+}$ oxygenated products to that for $\mathrm{C}_{2+}$ hydrocarbons. The selectivity to $\mathrm{C}_{2+}$ oxygenated products (ethanol, allyl alcohol and n-propanol) increases by a factor of two with increasing roughness, most likely due to the lower surface coverage by $* \mathrm{H}$, as reflected in the HER trend of Fig. 4, and the reduced likelihood of hydrogenating $\mathrm{C}-\mathrm{C}$ intermediates on the roughened $\mathrm{Cu}$ surfaces. Similarly, the selectivity to $\mathrm{HCOO}^{-}$decreases as the roughness increases from 1.0 to 2.6, and levels off thereafter (Fig. S7). We suggest that this trend is due to the lower availability of terrace sites on roughened $\mathrm{Cu}$ surfaces, which are needed to bond bidentate *HCOO, the precursor to $\mathrm{HCOOH}$ and hence $\mathrm{HCOO}^{-}$upon desorption of $\mathrm{HCOOH}$ into the alkaline electrolyte. ${ }^{6}$

A further factor that can contribute to enhancing the ratio of $\mathrm{C}_{2}+\mathrm{CH}_{4}$ on roughened vs smooth $\mathrm{Cu}$ surfaces is the higher local $\mathrm{pH}$ near the surface of the roughened $\mathrm{Cu}$; therefore, we considered the possible effect of $\mathrm{pH}$ on the observed results. The higher $\mathrm{pH}$ near the roughened surface is ascribable to the higher rate of $\mathrm{OH}^{-}$generation rate per geometric electrode area. We note that this proposal is consistent with the control experiment presented in Fig. S8, illustrating the effects of increased bicarbonate concentration, and the earlier findings of Hori et al., who reported a 4-fold enhancement in the $\mathrm{C}_{2} / \mathrm{CH}_{4}$ ratio upon increasing the surface $\mathrm{pH}$ from 8.5 to $9.5 .{ }^{54} \mathrm{In}$ our studies, we observed only a $\sim 2.6$-fold increase in the $\mathrm{C}_{2+} / \mathrm{CH}_{4}$ ratio due to an estimated increase in the surface $\mathrm{pH}$ change from 9.76 to 9.88 for $\mathrm{Cu}$ treated for 5-min vs. 10-min in an Ar plasma. The $\mathrm{pH}$ for these experiments was estimated assuming a mass-transfer boundary layer thickness of $\sim 40$ $\mu \mathrm{m}$ and a bicarbonate concentration of $0.1 \mathrm{M} .46,55 \mathrm{We}$ also note that it has been reported that the increase in surface $\mathrm{pH}$ as a consequence of electrolyte polarization should suppress $\mathrm{CH}_{4}$ production, but keep $\mathrm{C}_{2+}$ activity constant at a given potential. ${ }^{56}, 57$ Figure 3B shows that while the intrinsic activity (ECSA-normalized partial current density) for forming $\mathrm{CH}_{4}$ decreases following plasma 
pretreatment, the intrinsic activities for producing $\mathrm{C}_{2+}$ products, especially oxygenated products, increases. These observations suggest that the enhanced $\mathrm{C}_{2+}$ selectivity observed after plasma treatment is not attributable to the small change in the local $\mathrm{pH}$.

Table S1 compares our results on the effects of surface roughness with those previously reported. Various methods have been used to roughen the surface of $\mathrm{Cu}$. These include reduction of copper oxides produced by thermal and/or plasma oxidation, potential cycling in halogencontaining solutions, dendrite growth, etc. Regardless of the method used to achieve roughening, increased surface roughness generally leads to an enhanced $\mathrm{C}_{2+} \mathrm{FE}$ and $\mathrm{C}_{2+} / \mathrm{C}_{1}$ ratio. Most authors have attributed these effects enhanced surface roughness to a greater abundance of undercoordinated surface sites and defective sites that bind ${ }^{*} \mathrm{CO}$ strongly and promote its further reduction to $\mathrm{C}-\mathrm{C}$ bond formation. Unfortunately, these results cannot be compared with those reported here because of large difference in the modes of sample preparation and conditions for their inveistgation.

\section{Theoretical Simulation and Analysis}

Insights into why surface roughening causes an increase in the formation of $\mathrm{C}_{2+}$ products can be gained by atomic-level analysis of the $\mathrm{Cu}$ surface created by computational simulation of $\mathrm{Ar}^{+}$ bombardment roughening of a $\mathrm{Cu}(111)$ surface followed by thermal relaxation of the resulting surface. The simulation of roughening begins with a $17.6 \mathrm{~nm} \times 17.4 \mathrm{~nm}$ surface that $10.1 \mathrm{~nm}$ thick, which contains $\sim 5,422$ total surface atoms (see Fig. 6A). Figure 6B and the Supporting Movie 1 show that after bombardment of this surface with $1300 \mathrm{Ar}^{+}$cations, the $\mathrm{Cu}$ surface exposes 10,433 atoms, corresponding to an increase in surface roughness of 1.93. The simulated untreated $\mathrm{Cu}$ surface and the plasma-treated surface resemble the topography and roughness of the experimental observations, as seen in Figure 1. 
A
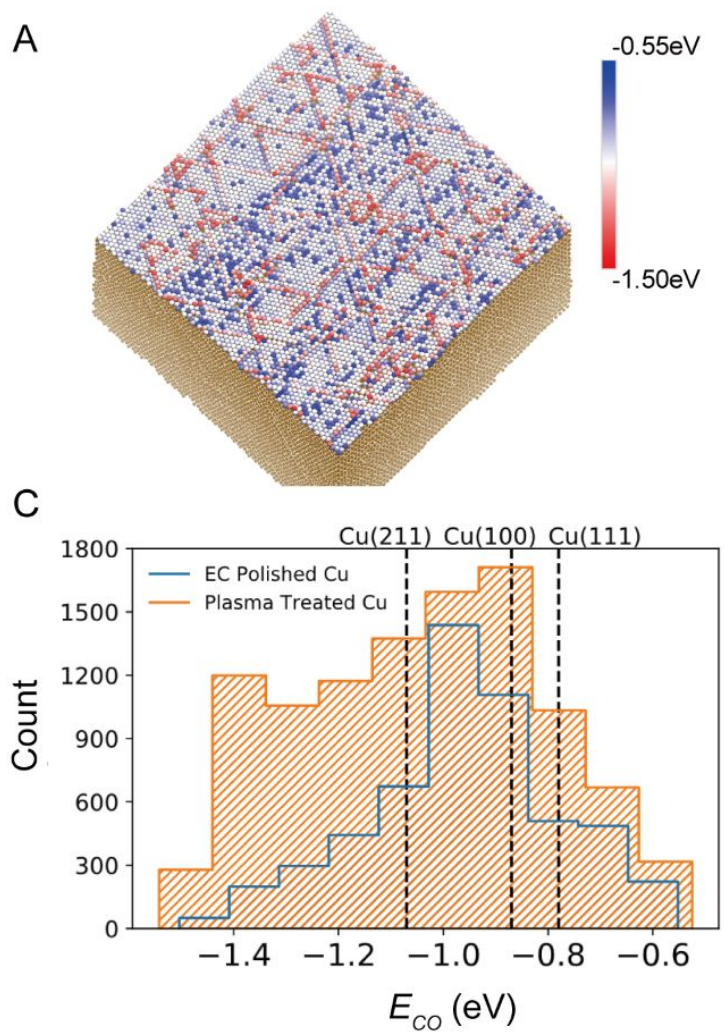

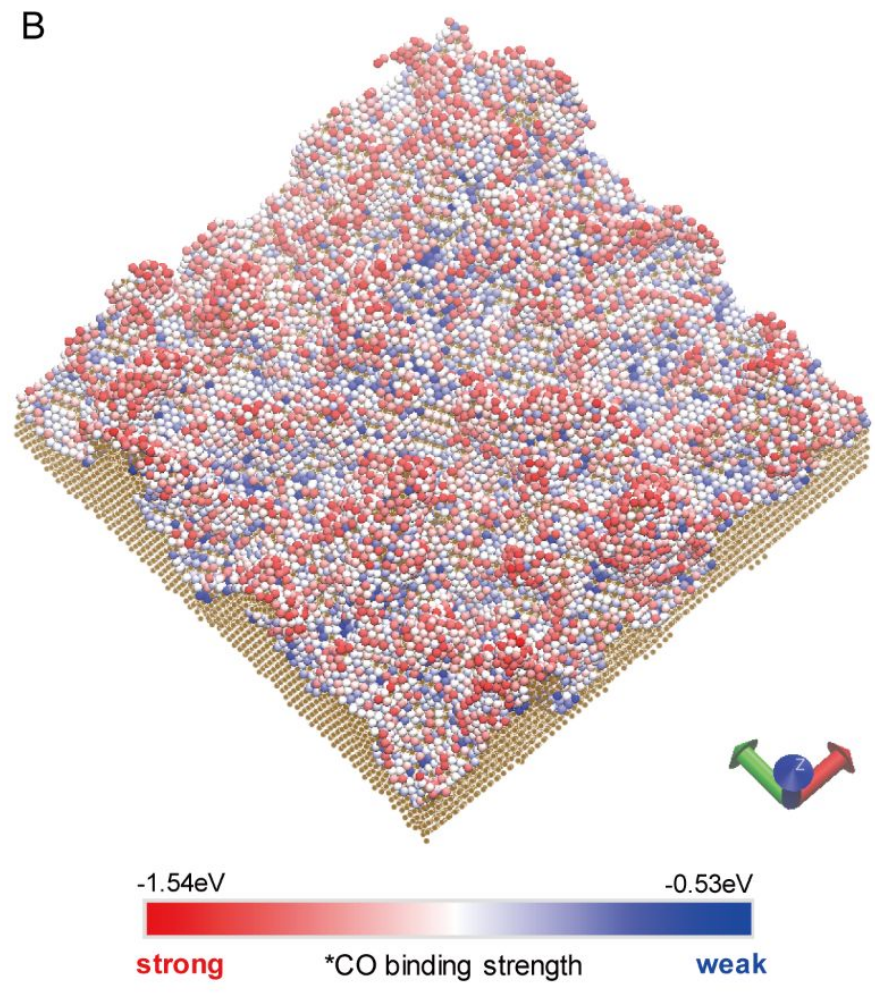

Figure 6. Active site visualization by ReaxQM-Machine Learning. Images of the computationally produced $\mathrm{Cu}$ surface of (A) electro-polished and (B) after Ar plasma bombardment, and (C) predicted distribution of $\mathrm{CO}$ adsorption energies, $\Delta \mathrm{E}_{\mathrm{CO}}$. The three dashed lines indicate the $\mathrm{CO}$ adsorption energies on $\mathrm{Cu}(111)$, (100) and (211).

The ReaxQM-Machine Learning approach was used to predict the distribution of CO binding energies, $\Delta \mathrm{E}_{\mathrm{CO}}$, for both simulated electrochemically polished $\mathrm{Cu}$ and the Ar plasma roughened surfaces. ${ }^{41,58}$ The electropolished $\mathrm{Cu}$, shown in Fig. 6A, is dominated by close-packed low index sites, and, therefore, the mean values of $\Delta \mathrm{E}_{\mathrm{CO}}$ are close to those of $\mathrm{Cu}(111),(100)$ and (211) surfaces (Fig. 6C). By contrast, a much higher population of stronger $\mathrm{CO}$ binding sites, ranging from -1.10 to $-1.54 \mathrm{eV}$ (red sites along the ridges in Fig. 6B and the columns left of the $\mathrm{Cu}(211)$ line in Fig. 6C), appear after plasma pretreatment. The increased number of strong CO binding sites is consistent with the experimental observation of a reduced selectivity to $\mathrm{CO}$ formation following plasma pretreatment to roughen the catalyst surface. Since the adsorption of $* \mathrm{CO}$ and ${ }^{*} \mathrm{H}$ are expected to compete on the surface of $\mathrm{Cu}$, the stronger adsorption of $\mathrm{CO}$ on roughened $\mathrm{Cu}$ is expected to result in a reduction of the $* \mathrm{H} /{ }^{*} \mathrm{CO}$. This reasoning would explain the increase in 
the formation of oxygenated relative to hydrocarbon products observed with increasing roughening seen in Fig. 5E.
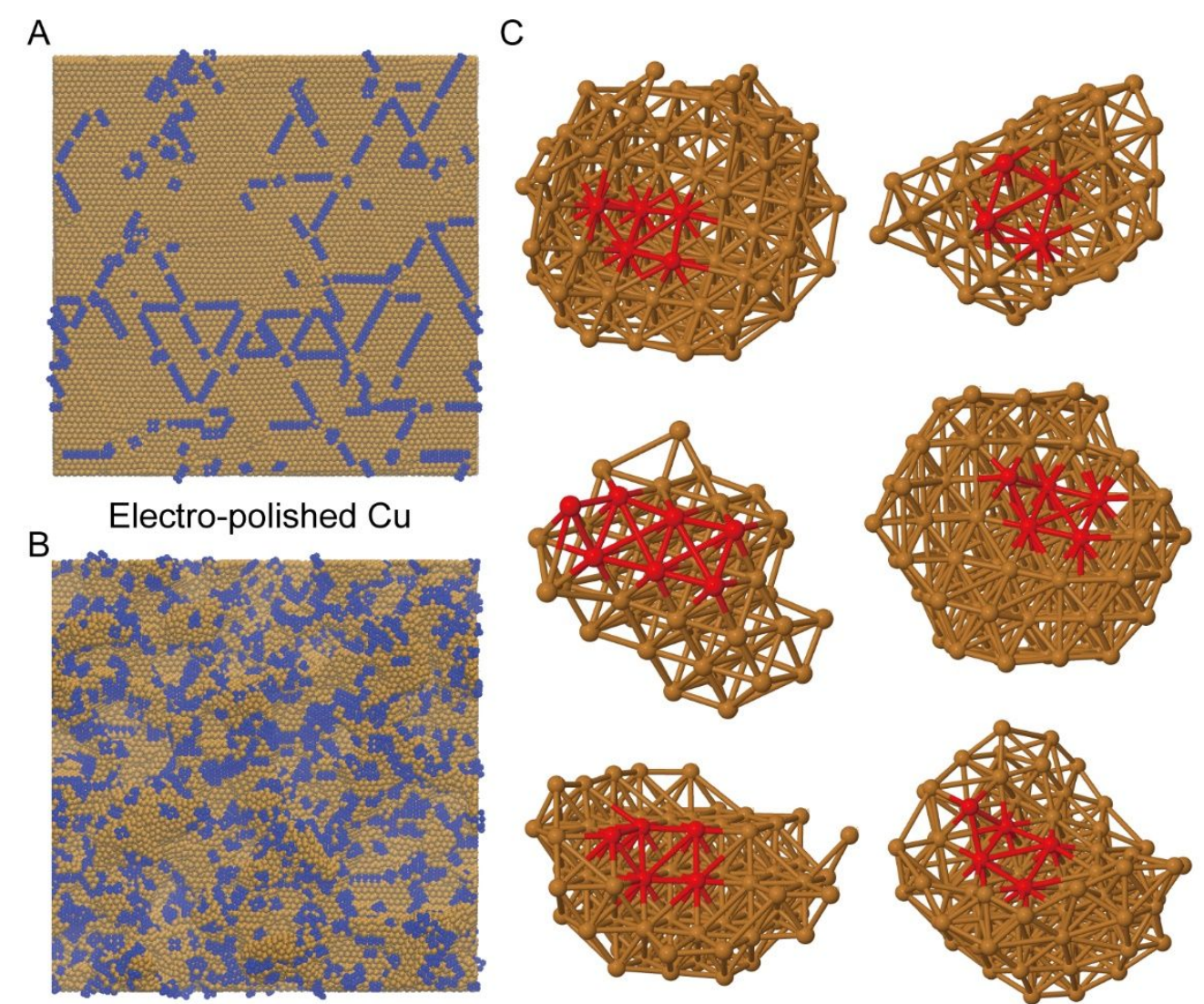

after Ar plasma treatment
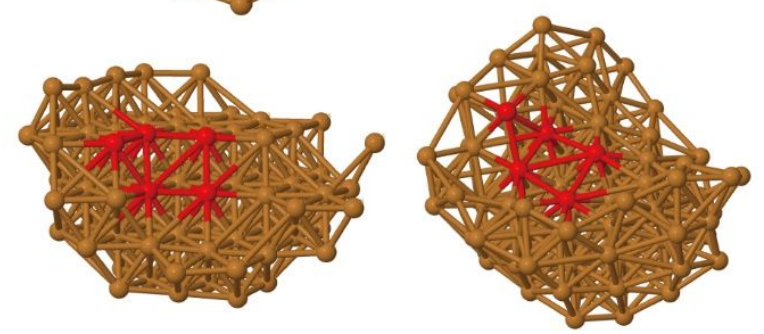

representative square sites

Figure 7. Visualization of square sites on computationally simulated $\mathrm{Cu}$ surfaces. (A) Electropolished $\mathrm{Cu}$ and (B) Ar plasma pretreated $\mathrm{Cu}$, the surface square sites are marked in blue color. (C) Zoomed-in atomic structure of randomly chosen square sites on the plasma-treated $\mathrm{Cu}$ surface, both the square sites and the neighboring $\mathrm{Cu}$ step sites (if any) are highlighted in red.

In our previous work we have employed the formation energy of $* \mathrm{OC}-\mathrm{COH}\left(\Delta \mathrm{E}_{\mathrm{OCCOH}}\right)$ as a descriptor for the selectivity of $\mathrm{C}_{2+}$ products formed during the $\mathrm{CO}_{2} \mathrm{RR}$, and have shown that the mean value of $\Delta \mathrm{E}_{\mathrm{OCCOH}}$ decreased from $\sim 1.35 \mathrm{eV}$ for random surface sites to $\sim 0.50 \mathrm{eV}$ for surface square sites. ${ }^{39}$ We also noted that concave defects located at $\mathrm{Cu}(100)$ plane next to a (111) step exhibited the most favorable values of $\Delta \mathrm{E}_{\mathrm{OCCOH}}$ for $\mathrm{C}_{2+}$ selectivity. In the present study, we identified the surface square sites on the simulated $\mathrm{Cu}$ surfaces for comparison as shown in Fig. $7 \mathrm{~A}$ and $7 \mathrm{~B}$. The percentage of square sites to overall surface atoms increased from $20.9 \%$ on the 
polished $\mathrm{Cu}$ surface to $38.5 \%$ on the surface produced by Ar plasma pretreatment. Fig. $7 \mathrm{C}$ shows the atomic structures of randomly chosen square sites occurring on the simulated surface produced by plasma treatment. The sites are similar to the $\mathrm{Cu}(100)$ configuration but have abundant neighboring step sites. As noted, the significantly increased percentage of surface square sites favors $\mathrm{C}-\mathrm{C}$ bond formation and provides a rational for the enhanced $\mathrm{C}_{2+}$ selectivity that correlates with increased surface roughening caused by plasma pretreatment.

In conclusion, the present study investigated the effects of surface topography on the activity and product selectivity of electrochemical $\mathrm{CO}_{2}$ reaction, demonstrating the distribution of products produced by $\mathrm{CO}_{2} \mathrm{RR}$ on metallic $\mathrm{Cu}$ changes with $\mathrm{Cu}$ surface topography created by plasma pretreatment. The activity and product selectivity of electrochemically polished $\mathrm{Cu}$ was compared with those of roughened $\mathrm{Cu}$ surfaces prepared by different plasma pretreatments. The differences in overall $\mathrm{CO}_{2} \mathrm{RR}$ activity from different plasma pretreatments are attributable changes in the electrochemically active surface area. Of particular note, we observe that with increasing surface roughness, the ratio of current densities for $\mathrm{CO}_{2} \mathrm{RR}$ to $\mathrm{HER}$, the ratio of the current densities for COR to the sum of the current densities for CO formation and COR, and the ratio of current densities for formation oxygenates to hydrocarbons all increase. These trends are interpreted based on an atomic-level analysis of the topogrphy of roughened $\mathrm{Cu}$ surface. We find that $\mathrm{CO}$ formed by the electrochemical reduction of $\mathrm{CO}_{2}$ binds more strongly on the roughened surface than on the electrochemically polished surface, suggesting that the ratio of adsorbed $\mathrm{H}$ to $\mathrm{CO}$ decreases with increasing surface roughness. These trends explain why the fraction of $\mathrm{CO}$ produced by $\mathrm{CO}_{2}$ reduction converted to reduced products and the fraction of these products appearing as oxygenates rather than hydrocarbons increase with increasing surface roughness. A further effect of increasing surface roughness is an increase in the fraction of final products (oxygenates and hydrocarbons) containing two or more $\mathrm{C}$ atoms. Our analysis shows that surface roughening increases the fraction of square sites similar to those on a $\mathrm{Cu}(100)$ surface but having abundant neighboring step sites. Prior work has shown that such sites enhance the formation of $\mathrm{C}-\mathrm{C}$ bonds required to form $\mathrm{C}_{2+}$ products during the electrochemical reduction of $\mathrm{CO}_{2}$. Finally, we find that increased roughening of the $\mathrm{Cu}$ surface increases the ratio of current densities for $\mathrm{C}_{2+}$ to $\mathrm{C}_{1}\left(\mathrm{CO}, \mathrm{HCOO}^{-}\right.$, and $\left.\mathrm{CH}_{4}\right)$ products up to a maximum value of $\sim 9$ for a surface roughness of $\sim 3$. Most of this downturn is ascribed to the enhanced formation of $\mathrm{CH}_{4}$ on surfaces with roughness in excess of 3 . The enhanced formation of methane on highly roughened surfaces is attributed to the formation of 
surface dimer and trimer clusters on the $\mathrm{Cu}$ surface that have been shown by theoretical calculation to serve as active sites for selective conversion of $\mathrm{CO}_{2}$ to $\mathrm{CH}_{4}$. In summary, the results of the present work highlight the importance of surface topography and defect sites on the observed $\mathrm{CO}_{2}$ reduction activity and selectivity, and suggest that rational surface structure engineering could contribute to the development of $\mathrm{Cu}$ electrocatalysts exhibiting a high selectivity to multi-carbon products.

\section{Supporting Information}

The Supporting Information is available free of charge on the ACS Publications website at DOI: $\mathrm{Xxx}$

Experimental and computational details; additional $\mathrm{Cu}$ electrodes characterization by AFM, SEM, Auger, XPS and electrochemical double-layer capacitance measurements; $\mathrm{Cu}$ surface roughness dependence of $\mathrm{CO}_{2}$ consumption rate and $\mathrm{FE}_{\text {formate }} / \mathrm{FE}_{(\mathrm{COg}+\mathrm{COR})}$ ratio during chronoamperometric electrolysis; online differential electrochemical mass spectrometry study on the cation effect; control experiments study on anion buffering effect and extra surface roughening at the presence of iodide anion

\section{Acknowledgements}

This material is based upon work performed by the Joint Center for Artificial Photosynthesis, a DOE Energy Innovation Hub, supported through the Office of Science of the U.S. Department of Energy under Award Number DE-SC0004993. We would also like to acknowledge Ms. LienChun Weng, Dr. Zhou Lin and Prof. Martin Head-Gordon for insightful discussions.

\section{References}

1. De Luna, P.; Hahn, C.; Higgins, D.; Jaffer, S. A.; Jaramillo, T. F.; Sargent, E. H., What would it take for renewably powered electrosynthesis to displace petrochemical processes? Science 2019, 364 (6438), eaav3506.

2. Shih, C. F.; Zhang, T.; Li, J.; Bai, C., Powering the Future with Liquid Sunshine. Joule 2018, 2 (10), 1925-1949.

3. Jouny, M.; Luc, W.; Jiao, F., General Techno-Economic Analysis of $\mathrm{CO}_{2}$ Electrolysis Systems. Ind. Eng. Chem. Res. 2018, 57 (6), 2165-2177. 
4. Verma, S.; Kim, B.; Jhong, H.; Ma, S. C.; Kenis, P. J. A., A Gross-Margin Model for Defining Technoeconomic Benchmarks in the Electroreduction of $\mathrm{CO}_{2}$. ChemSusChem 2016, 9 (15), 1972-1979.

5. Hori, Y.; Wakebe, H.; Tsukamoto, T.; Koga, O., Electrocatalytic Process of Co Selectivity in Electrochemical Reduction of $\mathrm{CO}_{2}$ at Metal-Electrodes in Aqueous-Media. Electrochim. Acta 1994, 39 (1112), 1833-1839.

6. Kortlever, R.; Shen, J.; Schouten, K. J. P.; Calle-Vallejo, F.; Koper, M. T. M., Catalysts and Reaction Pathways for the Electrochemical Reduction of Carbon Dioxide. J. Phys. Chem. Lett. 2015, 6 (20), 40734082.

7. Zhu, D. D.; Liu, J. L.; Qiao, S. Z., Recent Advances in Inorganic Heterogeneous Electrocatalysts for Reduction of Carbon Dioxide. Adv. Mater. 2016, 28 (18), 3423-3452.

8. Xu, S.; Carter, E. A., Theoretical Insights into Heterogeneous (Photo)electrochemical $\mathrm{CO}_{2}$ Reduction. Chem. Rev. 2019, 119 (11), 6631-6669.

9. Gao, D.; Arán-Ais, R. M.; Jeon, H. S.; Roldan Cuenya, B., Rational catalyst and electrolyte design for $\mathrm{CO}_{2}$ electroreduction towards multicarbon products. Nat. Catal. 2019, 2 (3), 198-210.

10. Nitopi, S.; Bertheussen, E.; Scott, S. B.; Liu, X.; Engstfeld, A. K.; Horch, S.; Seger, B.; Stephens, I. E. L.; Chan, K.; Hahn, C.; Norskov, J. K.; Jaramillo, T. F.; Chorkendorff, I., Progress and Perspectives of Electrochemical $\mathrm{CO}_{2}$ Reduction on Copper in Aqueous Electrolyte. Chem. Rev. 2019, 119 (12), 7610-7672. 11. Pérez-Gallent, E.; Marcandalli, G.; Figueiredo, M. C.; Calle-Vallejo, F.; Koper, M. T. M., Structureand Potential-Dependent Cation Effects on CO Reduction at Copper Single-Crystal Electrodes. J. Am. Chem. Soc. 2017, 139 (45), 16412-16419.

12. Kim, D.; Kley, C. S.; Li, Y.; Yang, P., Copper nanoparticle ensembles for selective electroreduction of $\mathrm{CO}_{2}$ to $\mathrm{C}_{2}-\mathrm{C}_{3}$ products. Proc. Natl. Acad. Sci. USA 2017, 114 (40), 10560-10565.

13. Resasco, J.; Chen, L. D.; Clark, E.; Tsai, C.; Hahn, C.; Jaramillo, T. F.; Chan, K.; Bell, A. T., Promoter Effects of Alkali Metal Cations on the Electrochemical Reduction of Carbon Dioxide. J. Am. Chem. Soc. 2017, 139 (32), 11277-11287.

14. Singh, M. R.; Kwon, Y.; Lum, Y.; Ager, J. W.; Bell, A. T., Hydrolysis of Electrolyte Cations Enhances the Electrochemical Reduction of $\mathrm{CO}_{2}$ over Ag and Cu. J. Am. Chem. Soc. 2016, 138 (39), 13006-13012.

15. Roberts, F. S.; Kuhl, K. P.; Nilsson, A., Electroreduction of Carbon Monoxide Over a Copper Nanocube Catalyst: Surface Structure and pH Dependence on Selectivity. ChemCatChem 2016, 8 (6), 1119-1124.

16. Kas, R.; Kortlever, R.; Yilmaz, H.; Koper, M. T. M.; Mul, G., Manipulating the Hydrocarbon Selectivity of Copper Nanoparticles in $\mathrm{CO}_{2}$ Electroreduction by Process Conditions. ChemElectroChem 2015, 2 (3), 354-358.

17. Hori, Y.; Takahashi, I.; Koga, O.; Hoshi, N., Selective Formation of $\mathrm{C}_{2}$ Compounds from Electrochemical Reduction of $\mathrm{CO}_{2}$ at a Series of Copper Single Crystal Electrodes. J. Phys. Chem. B 2002, $106(1), 15-17$.

18. Huang, Y.; Handoko, A. D.; Hirunsit, P.; Yeo, B. S., Electrochemical Reduction of $\mathrm{CO}_{2}$ Using Copper Single-Crystal Surfaces: Effects of CO* Coverage on the Selective Formation of Ethylene. ACS Catal. 2017, 7 (3), 1749-1756.

19. Loiudice, A.; Lobaccaro, P.; Kamali, E. A.; Thao, T.; Huang, B. H.; Ager, J. W.; Buonsanti, R., Tailoring Copper Nanocrystals towards C-2 Products in Electrochemical $\mathrm{CO}_{2}$ Reduction. Angew. Chem. Int. Edit. 2016, 55 (19), 5789-5792.

20. Jiang, K.; Sandberg, R. B.; Akey, A. J.; Liu, X.; Bell, D. C.; Nørskov, J. K.; Chan, K.; Wang, H., Metal Ion Cycling of $\mathrm{Cu}$ Foil for Selective $\mathrm{C}-\mathrm{C}$ Coupling in Electrochemical $\mathrm{CO}_{2}$ Reduction. Nat. Catal. 2018, 1, 111-119.

21. Schouten, K. J. P.; Pérez Gallent, E.; Koper, M. T. M., Structure Sensitivity of the Electrochemical Reduction of Carbon Monoxide on Copper Single Crystals. ACS Catal. 2013, 3 (6), 1292-1295.

22. Sandberg, R. B.; Montoya, J. H.; Chan, K.; Nørskov, J. K., CO-CO coupling on Cu facets: Coverage, strain and field effects. Surf. Sci. 2016, 654, 56-62.

23. Reske, R.; Mistry, H.; Behafarid, F.; Roldan Cuenya, B.; Strasser, P., Particle Size Effects in the Catalytic Electroreduction of $\mathrm{CO}_{2}$ on Cu Nanoparticles. J. Am. Chem. Soc. 2014, 136 (19), 6978-6986. 
24. Hahn, C.; Hatsukade, T.; Kim, Y. G.; Vailionis, A.; Baricuatro, J. H.; Higgins, D. C.; Nitopi, S. A.; Soriaga, M. P.; Jaramillo, T. F., Engineering $\mathrm{Cu}$ surfaces for the electrocatalytic conversion of $\mathrm{CO}_{2}$ : Controlling selectivity toward oxygenates and hydrocarbons. Proc. Natl. Acad. Sci. USA 2017, 114 (23), 5918-5923.

25. Wang, L.; Nitopi, S.; Wong, A. B.; Snider, J. L.; Nielander, A. C.; Morales-Guio, C. G.; Orazov, M.; Higgins, D. C.; Hahn, C.; Jaramillo, T. F., Electrochemically converting carbon monoxide to liquid fuels by directing selectivity with electrode surface area. Nat. Catal. 2019, 2 (8), 702-708.

26. Verdaguer-Casadevall, A.; Li, C. W.; Johansson, T. P.; Scott, S. B.; McKeown, J. T.; Kumar, M.; Stephens, I. E. L.; Kanan, M. W.; Chorkendorff, I., Probing the Active Surface Sites for CO Reduction on Oxide-Derived Copper Electrocatalysts. J. Am. Chem. Soc. 2015, 137 (31), 9808-9811.

27. Ren, D.; Deng, Y. L.; Handoko, A. D.; Chen, C. S.; Malkhandi, S.; Yeo, B. S., Selective Electrochemical Reduction of Carbon Dioxide to Ethylene and Ethanol on Copper(I) Oxide Catalysts. ACS Catal. 2015, 5 (5), 2814-2821.

28. Mistry, H.; Varela, A. S.; Bonifacio, C. S.; Zegkinoglou, I.; Sinev, I.; Choi, Y. W.; Kisslinger, K.; Stach, E. A.; Yang, J. C.; Strasser, P.; Cuenya, B. R., Highly selective plasma-activated copper catalysts for carbon dioxide reduction to ethylene. Nat. Commun. 2016, 7, 12123.

29. Lum, Y.; Yue, B.; Lobaccaro, P.; Bell, A. T.; Ager, J. W., Optimizing C-C Coupling on Oxide-Derived Copper Catalysts for Electrochemical $\mathrm{CO}_{2}$ Reduction. J. Phys. Chem. C 2017, 121 (26), 14191-14203.

30. Eilert, A.; Cavalca, F.; Roberts, F. S.; Osterwalder, J.; Liu, C.; Favaro, M.; Crumlin, E. J.; Ogasawara, H.; Friebel, D.; Pettersson, L. G. M.; Nilsson, A., Subsurface Oxygen in Oxide-Derived Copper Electrocatalysts for Carbon Dioxide Reduction. J. Phys. Chem. Lett. 2017, 8 (1), 285-290.

31. Gao, D. F.; Zegkinoglou, I.; Divins, N. J.; Scholten, F.; Sinev, I.; Grosse, P.; Cuenya, B. R., PlasmaActivated Copper Nanocube Catalysts for Efficient Carbon Dioxide Electroreduction to Hydrocarbons and Alcohols. ACS Nano 2017, 11 (5), 4825-4831.

32. Gao, D. F.; McCrum, I. T.; Deo, S.; Choi, Y. W.; Scholten, F.; Wan, W. M.; Chen, J. G. G.; Janik, M. J.; Cuenya, B. R., Activity and Selectivity Control in $\mathrm{CO}_{2}$ Electroreduction to Multicarbon Products over $\mathrm{CuO}_{\mathrm{x}}$ Catalysts via Electrolyte Design. ACS Catal. 2018, 8 (11), 10012-10020.

33. Garza, A. J.; Bell, A. T.; Head-Gordon, M., Is Subsurface Oxygen Necessary for the Electrochemical Reduction of $\mathrm{CO}_{2}$ on Copper? J. Phys. Chem. Lett. 2018, 9 (3), 601-606.

34. Fields, M.; Hong, X.; Nørskov, J. K.; Chan, K., Role of Subsurface Oxygen on Cu Surfaces for CO2 Electrochemical Reduction. J. Phys. Chem. C 2018, 122 (28), 16209-16215.

35. Lum, Y. W.; Ager, J. W., Stability of Residual Oxides in Oxide-Derived Copper Catalysts for Electrochemical $\mathrm{CO}_{2}$ Reduction Investigated with O-18 Labeling. Angew. Chem. Int. Edit. 2018, 57 (2), 551-554.

36. Kibria, M. G.; Dinh, C.-T.; Seifitokaldani, A.; De Luna, P.; Burdyny, T.; Quintero-Bermudez, R.; Ross, M. B.; Bushuyev, O. S.; García de Arquer, F. P.; Yang, P.; Sinton, D.; Sargent, E. H., A Surface Reconstruction Route to High Productivity and Selectivity in $\mathrm{CO}_{2}$ Electroreduction toward $\mathrm{C}_{2+}$ Hydrocarbons. Adv. Mater. 2018, 30 (49), 1804867.

37. Mandal, L.; Yang, K. R.; Motapothula, M. R.; Ren, D.; Lobaccaro, P.; Patra, A.; Sherburne, M.; Batista, V. S.; Yeo, B. S.; Ager, J. W.; Martin, J.; Venkatesan, T., Investigating the Role of Copper Oxide in Electrochemical $\mathrm{CO}_{2}$ Reduction in Real Time. ACS Appl. Mater. Interfaces 2018, 10 (10), 8574-8584.

38. Farmand, M.; Landers, A. T.; Lin, J. C.; Feaster, J. T.; Beeman, J. W.; Ye, Y.; Clark, E. L.; Higgins, D.; Yano, J.; Davis, R. C.; Mehta, A.; Jaramillo, T. F.; Hahn, C.; Drisdell, W. S., Electrochemical flow cell enabling operando probing of electrocatalyst surfaces by X-ray spectroscopy and diffraction. Phys. Chem. Chem. Phys. 2019, 21 (10), 5402-5408.

39. Scott, S. B.; Hogg, T. V.; Landers, A. T.; Maagaard, T.; Bertheussen, E.; Lin, J. C.; Davis, R. C.; Beeman, J. W.; Higgins, D.; Drisdell, W. S.; Hahn, C.; Mehta, A.; Seger, B.; Jaramillo, T. F.; Chorkendorff, I., Absence of Oxidized Phases in $\mathrm{Cu}$ under CO Reduction Conditions. ACS Energy Lett 2019, 4 (3), 803804.

40. Lei, Q.; Zhu, H.; Song, K.; Wei, N.; Liu, L.; Zhang, D.; Yin, J.; Dong, X.; Yao, K.; Wang, N.; Li, X.; Davaasuren, B.; Wang, J.; Han, Y., Investigating the Origin of Enhanced $\mathrm{C}_{2+}$ Selectivity in Oxide- 
/Hydroxide-Derived Copper Electrodes during $\mathrm{CO}_{2}$ Electroreduction. J. Am. Chem. Soc. 2020, 142 (9), 4213-4222..

41. Huang, Y.; Chen, Y.; Cheng, T.; Wang, L.-W.; Goddard, W. A., Identification of the Selective Sites for Electrochemical Reduction of $\mathrm{CO}$ to $\mathrm{C}_{2+}$ Products on Copper Nanoparticles by Combining Reactive Force Fields, Density Functional Theory, and Machine Learning. ACS Energy Lett 2018, 3 (12), 2983-2988. 42. Tang, W.; Peterson, A. A.; Varela, A. S.; Jovanov, Z. P.; Bech, L.; Durand, W. J.; Dahl, S.; Norskov, J. K.; Chorkendorff, I., The importance of surface morphology in controlling the selectivity of polycrystalline copper for $\mathrm{CO}_{2}$ electroreduction. Phys. Chem. Chem. Phys. 2012, 14 (1), 76-81.

43. Chiang, C.-C.; Chen, M.-C.; Li, L.-J.; Wu, Z.-C.; Jang, S.-M.; Liang, M.-S., Effects of $\mathrm{O}_{2}$-and $\mathrm{N}_{2}-$ plasma treatments on copper surface. Japn. J. Appl. Phys. 2004, 43 (11R), 7415.

44. Fatyeyeva, K.; Dahi, A.; Chappey, C.; Langevin, D.; Valleton, J.-M.; Poncin-Epaillard, F.; Marais, S., Effect of cold plasma treatment on surface properties and gas permeability of polyimide films. $R S C A d v$. 2014, 4 (59), 31036-31046.

45. Deng, Y. L.; Handoko, A. D.; Du, Y. H.; Xi, S. B.; Yeo, B. S., In Situ Raman Spectroscopy of Copper and Copper Oxide Surfaces during Electrochemical Oxygen Evolution Reaction: Identification of Cu-III Oxides as Catalytically Active Species. ACS Catal. 2016, 6 (4), 2473-2481.

46. Clark, E. L.; Resasco, J.; Landers, A.; Lin, J.; Chung, L.-T.; Walton, A.; Hahn, C.; Jaramillo, T. F.; Bell, A. T., Standards and Protocols for Data Acquisition and Reporting for Studies of the Electrochemical Reduction of Carbon Dioxide. ACS Catal. 2018, 8 (7), 6560-6570.

47. Ringe, S.; Clark, E. L.; Resasco, J.; Walton, A.; Seger, B.; Bell, A. T.; Chan, K., Understanding cation effects in electrochemical CO2 reduction. Energy Environ. Sci. 2019, 12 (10), 3001-3014.

48. Peterson, A. A.; Abild-Pedersen, F.; Studt, F.; Rossmeisl, J.; Norskov, J. K., How copper catalyzes the electroreduction of carbon dioxide into hydrocarbon fuels. Energy Environ. Sci. 2010, 3 (9), 1311-1315.

49. Garza, A. J.; Bell, A. T.; Head-Gordon, M., Mechanism of $\mathrm{CO}_{2}$ Reduction at Copper Surfaces: Pathways to C2 Products. ACS Catal. 2018, 8 (2), 1490-1499.

50. Zheng, Y.; Vasileff, A.; Zhou, X.; Jiao, Y.; Jaroniec, M.; Qiao, S. Z., Understanding the Roadmap for Electrochemical Reduction of $\mathrm{CO}_{2}$ to Multi-Carbon Oxygenates and Hydrocarbons on Copper-Based Catalysts. J. Am. Chem. Soc. 2019, 141 (19), 7646-7659.

51. Malkani, A. S.; Dunwell, M.; Xu, B., Operando Spectroscopic Investigations of Copper and OxideDerived Copper Catalysts for Electrochemical CO Reduction. ACS Catal. 2019, 9 (1), 474-478.

52. Cheng, T.; Xiao, H.; Goddard, W. A., Nature of the Active Sites for CO Reduction on Copper Nanoparticles; Suggestions for Optimizing Performance. J. Am. Chem. Soc. 2017, 139 (34), 11642-11645. 53. Zhao, Z. L.; Chen, Z. Z.; Zhang, X.; Lu, G., Generalized Surface Coordination Number as an Activity Descriptor for $\mathrm{CO}_{2}$ Reduction on Cu Surfaces. J. Phys. Chem. C 2016, 120 (49), 28125-28130.

54. Hori, Y.; Murata, A.; Takahashi, R., Formation of hydrocarbons in the electrochemical reduction of carbon dioxide at a copper electrode in aqueous solution. J. Chem. Soc., Faraday Trans. 1 F 1989, 85 (8), 2309-2326.

55. Weng, L. C.; Bell, A. T.; Weber, A. Z., Towards membrane-electrode assembly systems for $\mathrm{CO}_{2}$ reduction: a modeling study. Energy Environ. Sci. 2019, 12 (6), 1950-1968.

56. Hori, Y.; Takahashi, R.; Yoshinami, Y.; Murata, A., Electrochemical Reduction of CO at a Copper Electrode. J. Phys. Chem. B 1997, 101 (36), 7075-7081.

57. Resasco, J.; Lum, Y.; Clark, E.; Zeledon, J. Z.; Bell, A. T., Effects of Anion Identity and Concentration on Electrochemical Reduction of $\mathrm{CO}_{2}$. ChemElectroChem 2018, 5 (7), 1064-1072.

58. Chen, Y.; Huang, Y.; Cheng, T.; Goddard, W. A., Identifying Active Sites for $\mathrm{CO}_{2}$ Reduction on Dealloyed Gold Surfaces by Combining Machine Learning with Multiscale Simulations. J. Am. Chem. Soc. 2019, 141 (29), 11651-11657. 


\section{Table of Contents Graphic}

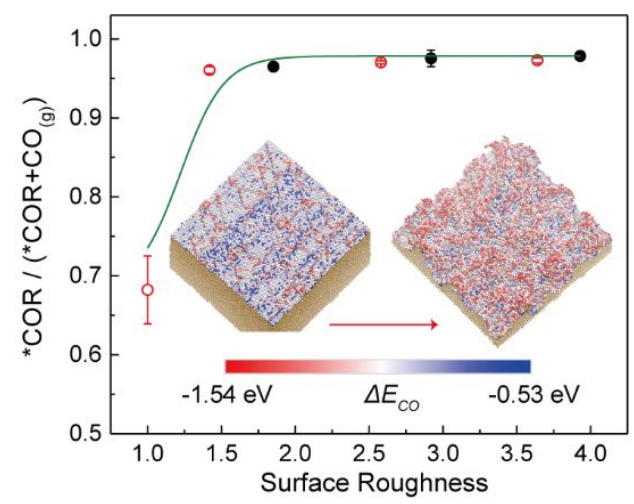

